\title{
The Diabetic Syndrome in the Tuco-Tuco (Ctenomys talarum)
}

\author{
P.H. WISE ${ }^{1}$, B.J.WELR ${ }^{2}$, J.M. HIME ${ }^{3}$, and E. ForResT ${ }^{1}$ \\ 1. Department of Medicine, Guy's Hospital Medical School, London S.E.l.*2. Wellcome Institute of Comparative \\ Physiology and 3. Veterinary Hospital, The Zoological Society of London, Regent's Park, London N.W.!. England
}

Received: November 9, 1971, accepted: March 3, 1972

Summary. A syndrome of diabetes, which appears to be dependent upon diet, is described in an Argentine rodent, the tuco-tuco. Hyperglycaemia and cataract are shown to be inversely related to age and associated with excess mortality. Pancreatic islet, renal glomerular and lens changes are similar to those of human diabetics. It is suggested that this species forms a useful model of human maturity onset diabetes.

Le syndrome diabétique chez le Tuco-tuco (Ctenomys talarum)

Résumé. Les auteurs décrivent un syndrome diabétique, qui semble dépendre du régime, chez un rongeur d'Argentine, le tuco-tuco. - L'hyperglycémie et la cataracte sont en relation inverse avec l'âge et sont associées à un excès de mortalité. Les modifications des îlots pancréatiques, des glomérules rénaux et du cristallin sont semblables à celles observées chez les diabétiques hu- mains. - Il est suggéré que cette espèce constitue un modèle utile pour le diabète humain de la maturité.

Das Diabetessyndrom bei Tuco-tuco (Ctenomys talarum)

Zusammenfassung. Bei einem argentinischen Nagetier, dem Tuco-Tuco, wird ein Diabetessyndrom beschrieben, das von der Nahrungszufuhr abhängig zu sein scheint. Hyperglykämie und Katarakt scheinen in umgekehrter Beziehung zum Alter zu stehen. Sie sind mit erhöhter Mortalität verbunden. Die Veränderungen am Inselapparat, am Pankreas, an den Glomerula der Niern und an der Linse sind ähnlich wie beim menschlichen Diabetes. - Es wird betont, daß diese Species mit Vorteil als Modell für den menschlichen, spät-manifesten Diabetes angesehen werden kann.

Key words: Spontaneous diabetic syndrome, tuco-tuco, captivity, maturity onset diabetes.
Spontaneous diabetes mellitus has been demonstrated in a variety of species $[1,2]$, but its prevalence in any one captive group has been low except for the Egyptian sand rat [3], the spiny mouse [4] and the tree shrew [5]. A demand exists for an animal model of human diabetes to study the epidemiology and genetics of the disease and the interrelation of vascular lesions to the metabolic defects. Readily available

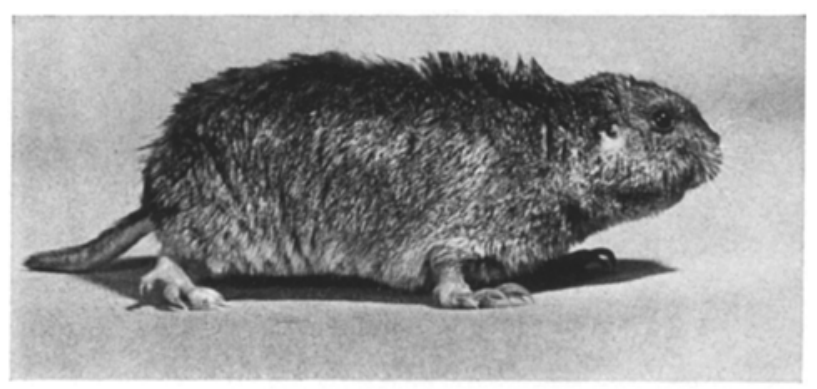

Fig. 1. An adult female tuco-tuco ( $x$ 0.4)

animals are needed to assess the hypoglycaemic action of new drugs to counteract spontaneous diabetes. The present report analyses the features of a diabetic condition identified in a burrowing hystricomorph rodent (Fig. 1), the tuco-tuco, Ctenomys talarum [6]. A number of these animals was obtained from the Province of

* Endocrine Unit, Royal Adelaide Hospital, North Terrace, Adelaide, South Australia 5000
Buenos Aires, Argentina, by one of us (B.J.W.) to study their reproductive physiology but cataracts were the features which led to the present investigation.

\section{Animals and methods}

Eighty-one tuco-tucos (weighing $85-210$ g) were trapped [7] in Argentina in July 1967 and established in London; these are referred to as the parent colony. Most of the 61 females were pregnant when captured and 27 produced litters of $1-6$ young between September and November 1967. These offspring are referred to as the $\mathbf{F}_{1}$ generation.

The animals were housed and fed (Fig. 4) as previously described. The diet offered to half the colony was varied. as shown in Fig. 4. After cataracts had been seen in $F_{1}$ generation tuco-tucos, in January 1968 , all the $F_{1}$ animals were examined in February 1968, by the method described by Wise et al. [6].

A retrobulbar bleeding technique was used on the left eye of each unfasted animal to obtain $50 \mu$ l samples of blood [8]. These were analysed for total blood sugar using a modified micro-ferricyanide method in an Autoanalyser [9]. Twenty-four hour urine samples were collected from 78 tuco-tucos and tested for sugar, ketones, protein and $\mathrm{pH}$ by test strips and tablets (Ames). Most animals were tested once only but urine samples were collected from 17 animals on two or more occasions.

Insulin sensitivity tests were carried out in 41 animals using erystalline bovine insulin. Twenty-six received an intraperitoneal injection of $0.5 \mathrm{units} / \mathrm{kg}$ and 15 received 16 units $/ \mathrm{kg}$. Blood sugar estimations were made at 0,30 , 60 and $120 \mathrm{~min}$. Glucose tolerance tests were carried out on 28 animals; D-glucose $(250 \mathrm{mg} / \mathrm{kg}$ ) was administered by intraperitoneal injection and blood sugar levels estimated at $0,30,60$ and $120 \mathrm{~min}$. For both these tests, 


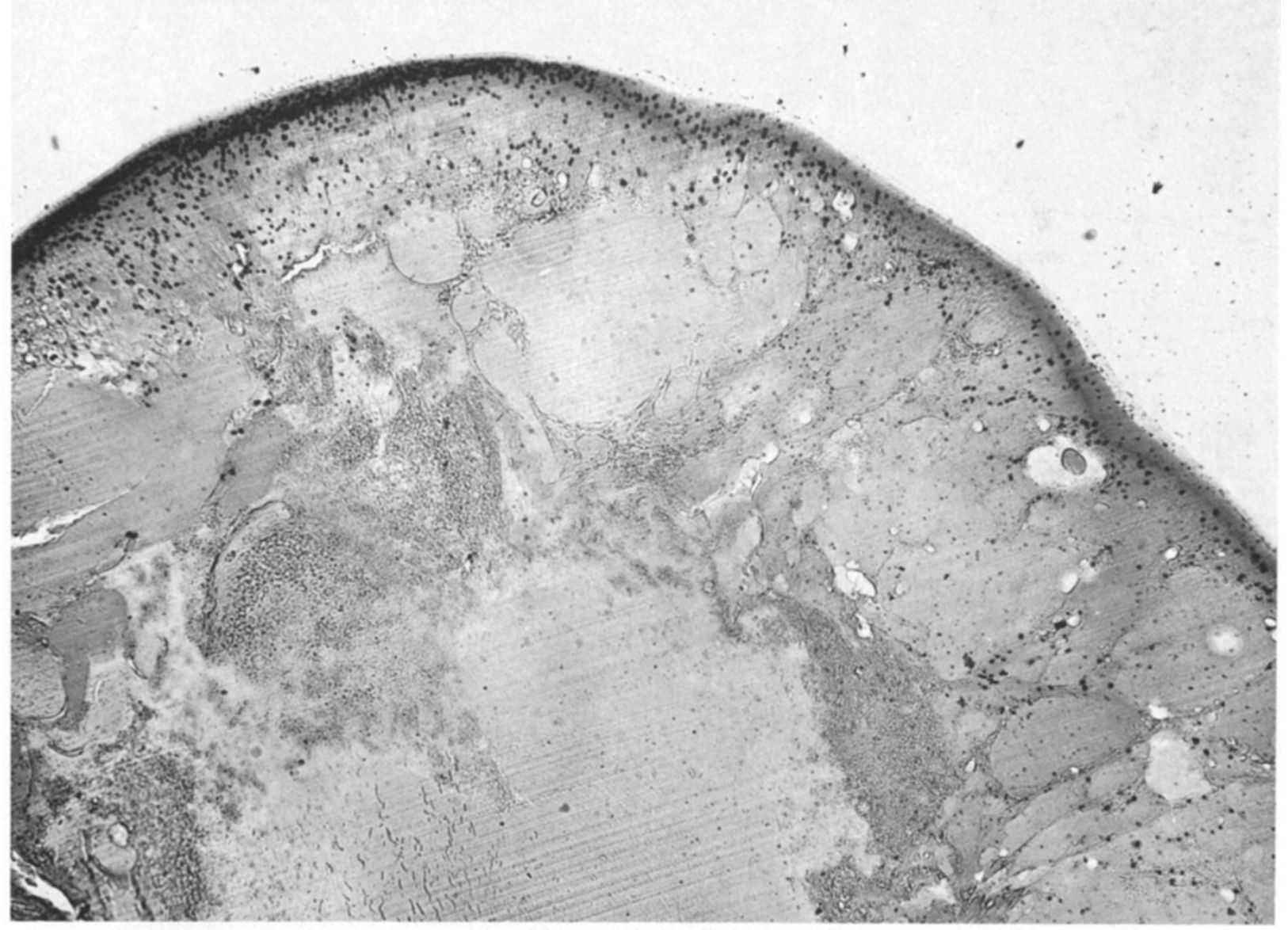

Fig. 2. Section of a cataractous lens showing nuclear invasion and vacuolar disruption $(\times 189)$

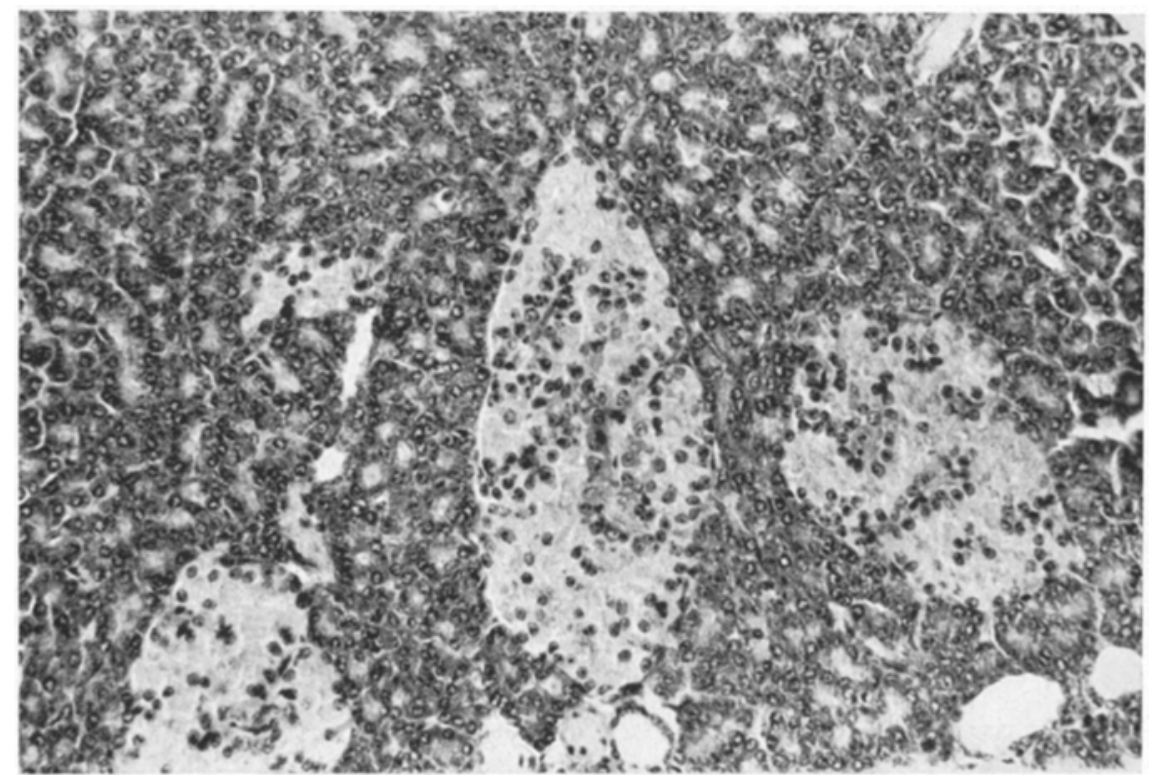

Fig. 3. Islet hyperplasia and hypertrophy $(\times 80)$ 
normo- and hyperglycaemic animals with and without cataracts were included.

Data on reproduction were obtained and are presented in a separate communication [10].

Tissues from all animals killed or found dead were removed at autopsy for routine or special histology. The gonads, reproductive tracts, pancreas and kidney were fixed in Bouin's fluid and embedded in paraffin wax. Eyes were preserved in $5 \%$ formol saline or formol-acetic-alcohol and embedded in celloidin or paraffin wax. Sections

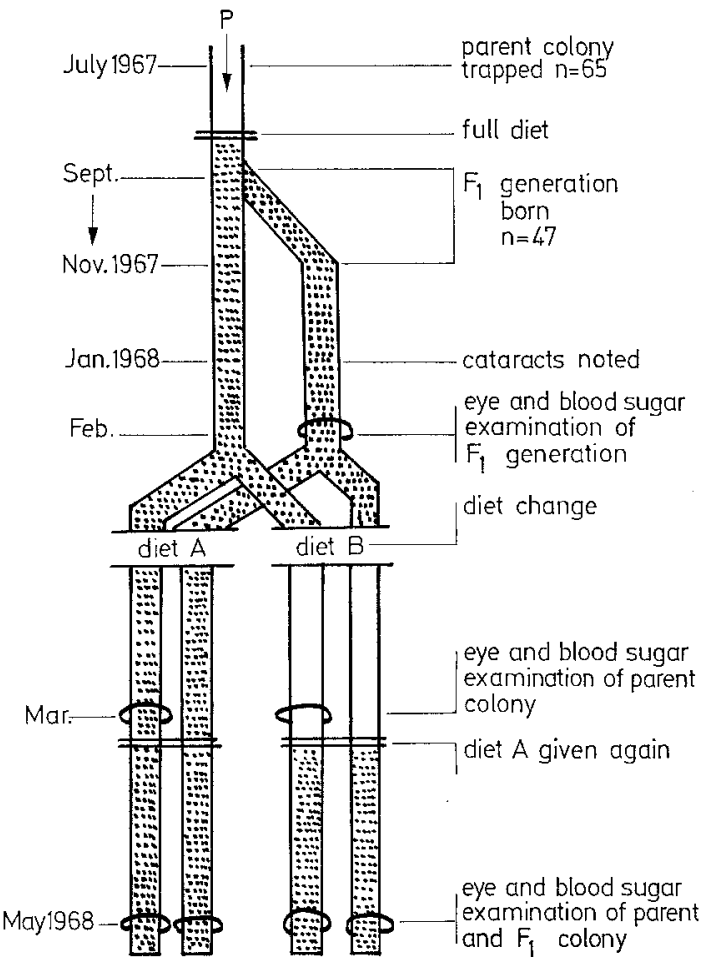

Fig. 4. Flow diagram to show the sequence of events in the tuco-tuco colony : Full diet = hay and water ad libitum, cabbage, carrot, potato and compound diet pellets (Diet 86, Dixons) daily. Diet $\mathrm{A}=$ hay and water ad libitum, cabbage, carrot and potato on Mondays, Wednesdays and Fridays, compound diet pellets on Tuesdays, Thursdays and Saturdays. Diet B $=$ as for Diet A but no compound diet pellets

Table 1. Weight changes of wild tuco-tucos 6 months after capture

\begin{tabular}{|c|c|c|c|}
\hline & Males & & Females \\
\hline No. & $\begin{array}{l}\text { Mean weight } \pm \text { S.E. } \\
\text { at capture }\end{array}$ & No. & $\begin{array}{l}\text { Mean weight } \pm \text { S.E. } \\
\text { at capture }\end{array}$ \\
\hline 40 & $\begin{array}{l}165.9+14.0^{\mathrm{a}} \\
\text { after } 6 \text { months }\end{array}$ & 76 & $\begin{array}{l}127.8^{+}+6.7^{\mathrm{a}} \\
\text { after } 6 \text { months }\end{array}$ \\
\hline 14 & $197.2 \pm 6.1^{\mathrm{a}}$ & 51 & $152.3 \pm 7.5^{\mathrm{a}}$ \\
\hline
\end{tabular}

a Significantly different $P<0.001$.

were cut at 5-10 $\mathrm{mm}$ according to the tissue and the stains used were: Mayer's haemalum and eosin, Azan, aldehyde fuchsin-orange G-light green, periodic acidSchiff with celestin blue counterstain, and silver nitrate.

Standard statistical tests were applied and mean values are given with the standard error of the mean.
It was not possible to estimate the frequency of diabetes throughout the colony at the different stages of management because, as shown in Fig. 4, the whole colony (parents and $\mathrm{F}_{1}$ generation) was tested for blood sugar levels and cataractous state on only one occasion. The initial study was done on the $\mathrm{F}_{1}$ animals and the other tests were performed on mixed samples throughout the period February to May 1968.

\section{Results}

\section{Clinical and biochemical observations}

\section{Body weight and blood sugar levels}

The weight changes of the parent colony are shown in Table 1. A correlation was found between blood. sugar and body weight at the time of sampling ( $r=$ $0.61, P=0.001$ ) (Fig. 5) but an inverse trend existed

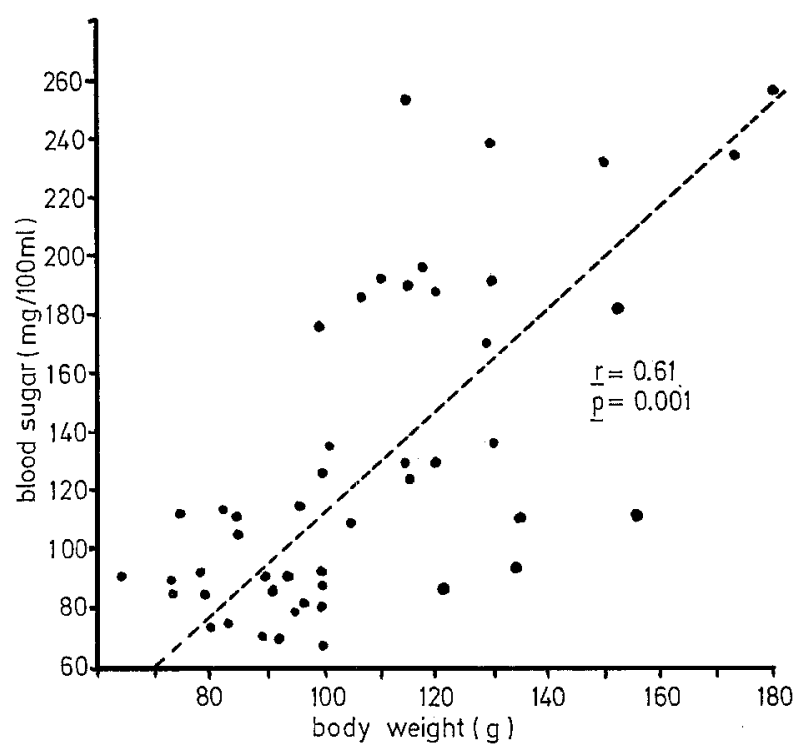

Fig. 5. Diagram showing the positive correlation between blood sugar levels and body weight of $F_{1}$ tuco-tucos at the time of sampling

between age and blood sugar $(r=-0.27)$ which did not reach significance $(0.05<P<0.1)$. When the colony was subdivided according to lens appearance (Fig. 6) those animals on Diet $\mathbf{A}$ showed a higher blood sugar concentration; cataractous animals had levels of $145 \pm 20 \mathrm{mg}$ per cent and non-cataractous animals $106 \pm 6 \mathrm{mg}$ per cent $(P=0.01)$. Dietary restriction. (Diet B) apparently corrected the blood sugar levels and no significant difference was found between the mean values for the groups with and without cataract. Body weight of animals on Diet B (149 $\pm 5.4 \mathrm{~g})$ was significantly lower $(0.025<P<0.05)$ than those on Diet $A(164 \pm 4.1 \mathrm{~g})$. The frequency distribution plot of the blood sugar levels of all 72 animals on the unrestricted diet showed that the population distribution. was continuous. When mean blood sugar levels of the females of the parent colony were compared with those of their respective litters, a significant positive correlation was demonstrated $(r=0.663,0.001<P<0.01)$. 


\section{Urine analysis}

The volume of 156 urine samples ranged from $0.5-22.0 \mathrm{ml}$ although most varied only between $3.0-5.0 \mathrm{ml}$. Thirty-four animals had $\mathrm{pH}$ values of 7.0

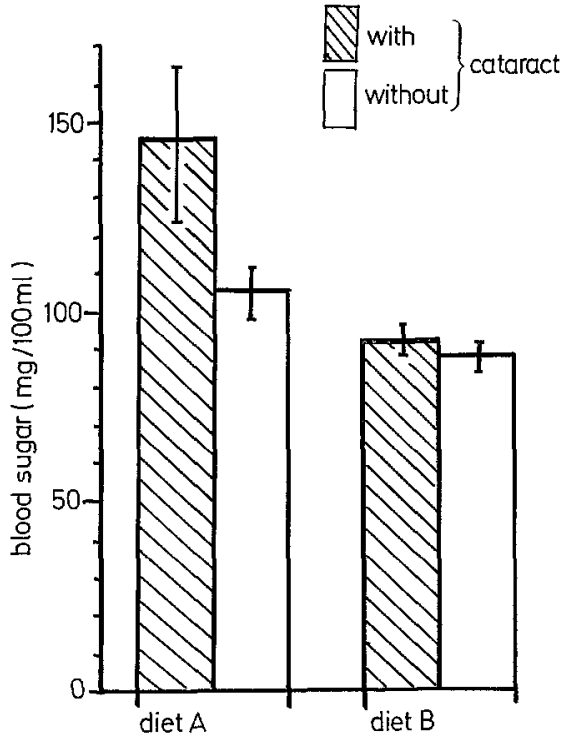

Fig. 6. Comparison of blood sugar concentrations of cataractous and non-cataractous parent colony tuco-tucos on Diets A and B (mean \pm S.E.M.). The difference between the groups on Diet $\mathrm{A}$ is significant $(P=0.01)$

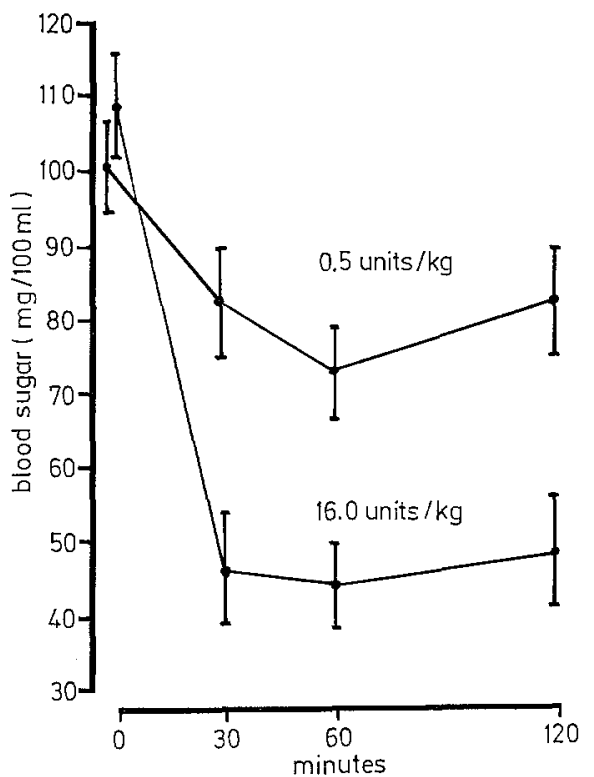

Fig. 7. Mean blood sugar concentrations ( \pm S.E.M.) over a period of $2 \mathrm{~h}$ of tuco-tucos treated with insulin at 2 dose levels

or more, but the remaining values were at 6.0 . Protein was present in all but 13 samples. Glucose values ranged from $0.25 \mathrm{~g} / 100 \mathrm{ml}$ for most animals to over $2.0 \mathrm{~g} / 100 \mathrm{ml}$ in 7 animals, of which $4 \mathrm{had}$ normal lenses. Glycosuria was found in 30 of $35(86 \%)$ cata- ractous and 30 of $43(70 \%)$ non-cataractous animals. Ketones were found in the urine of 8 cataractous animals, of which 6 were also hyperglycaemic, and in 6 non-cataractous animals, of which only one had a blood sugar level greater than $100 \mathrm{mg}$ per cent.

\section{Insulin sensitivity tests}

The effect of insulin at the two dose levels on blood. sugar levels in the tuco-tucos is shown in Fig. 7. Neither group had previously received insulin and the composition of each was identical in terms of cataractous and hyperglycaemic animals. Blood sugar levels, both absolute and relative to the fasting level, showed no correlation with body weight at any time for either insulin dosage. At the lower dose rate of $0.5 \mathrm{~kg}$, the percentage fall in blood sugar was directly related to the fasting level at 30 and $60 \mathrm{~min}(P=0.05)$ and the $120 \mathrm{~min}$ blood sugar level was closely correlated with. the fasting level $(r=0.82, P<0.001)$. On the higher dose only one animal showed symptomatic evidence of hypoglycaemia.

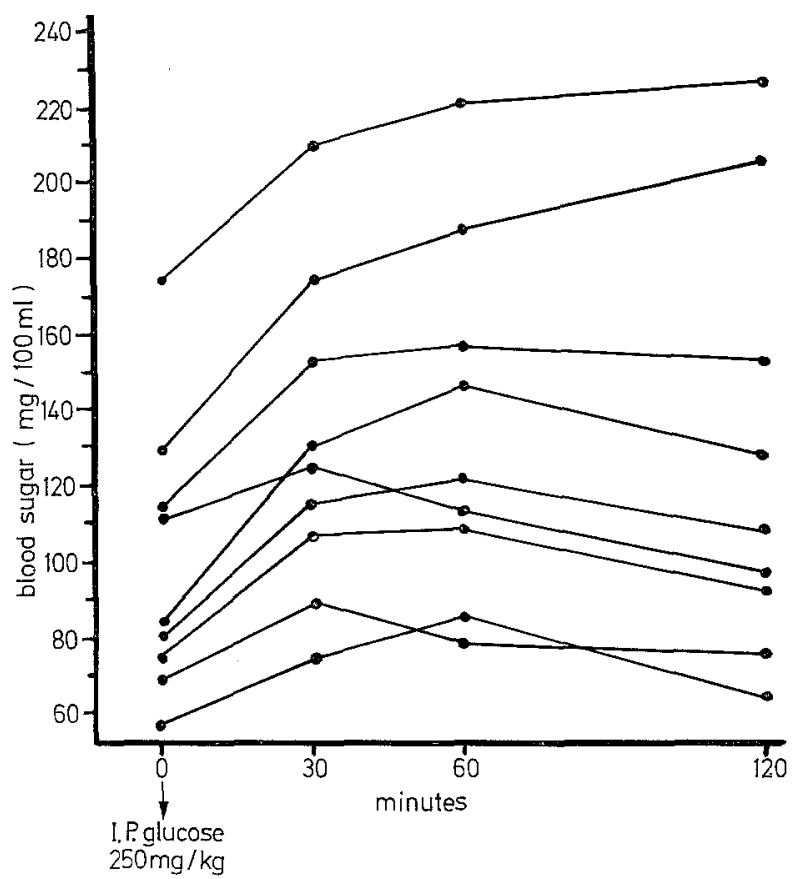

Fig. 8. Range of responses to glucose loading $(250 \mathrm{mg} / \mathrm{kg})$ in tuco-tucos

\section{Glucose tolerance tests}

A wide range of responses was recorded with no clear division into 'normal' and 'abnormal' types. A selection showing the range of these responses is given in Fig. 8. No examples of reactive hypoglycaemia were recorded. The sum of blood glucose levels at each time point showed a high correlation with body weight.

\section{Cataracts}

A refractive change, seen only at the periphery of the lens with complete mydriasis (Fig. 9a), was found 
in $8 \mathrm{~F}_{1}$ animals $(17 \%)$ and was thought to represent the earliest change. A further $19 \mathrm{~F}_{1}$ animals $(40 \%)$ showed definite structural lens abnormality. Vacuoles, either central or peripheral, were the most obvious change (Figs. $9 \mathrm{~b}$ and $\mathrm{c}$ ). More advanced lesions such as clefts and wedges, patchy polar cataracts (Fig. 9d)
$(P=0.001)$. The animals were allocated according to the condition of the less affected eye of a pair (Fig. 10). The spectrum of lens change in the parent colony was similar to that in the $\mathrm{F}_{1}$ colony (Fig. 9), but only 12 animals $(18.5 \%)$ showed structural abnormalities, significantly fewer than in the $F_{1}$ generation $\left(\mathrm{X}^{2}=5.47\right.$,

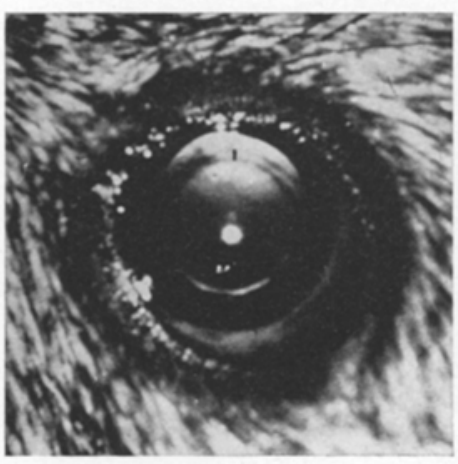

a

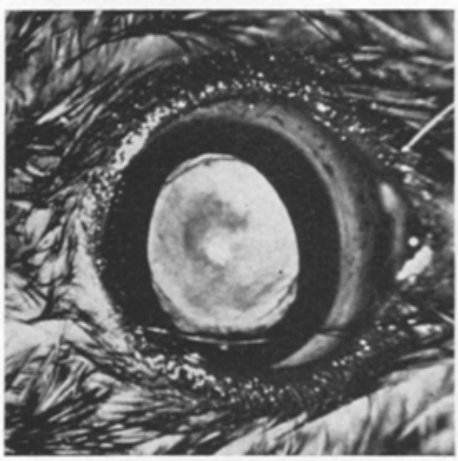

d

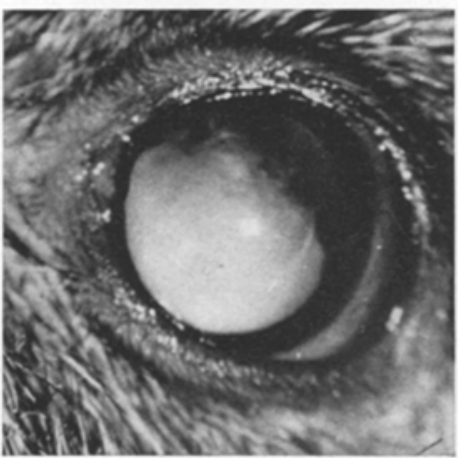

g

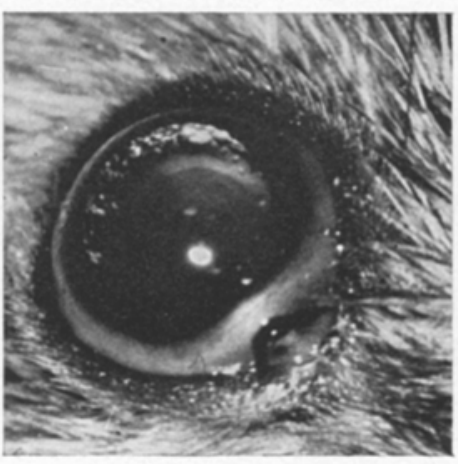

b
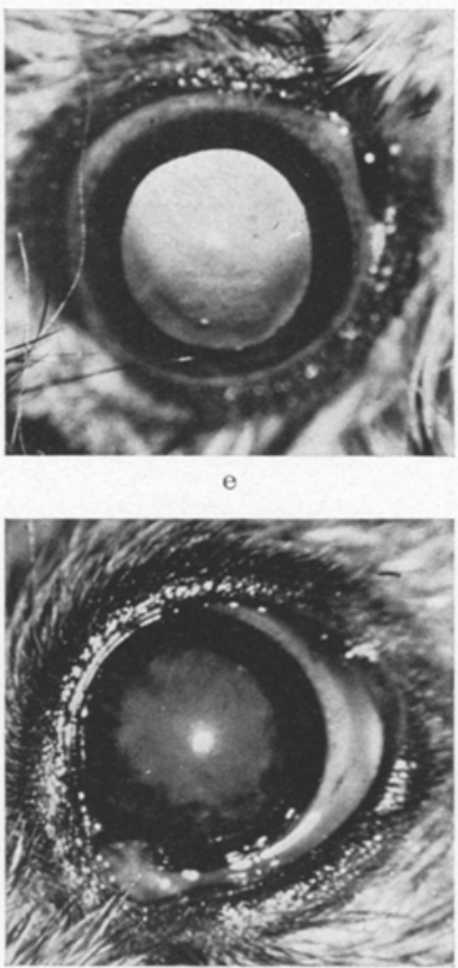

$\mathrm{h}$

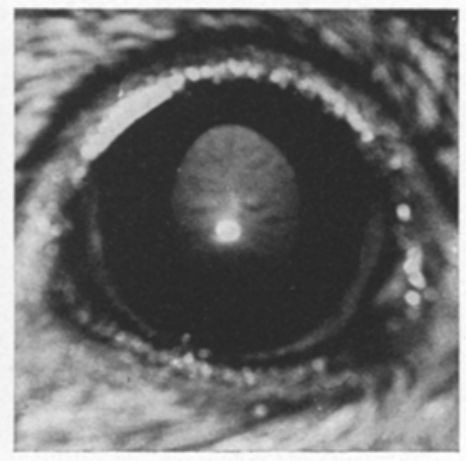

c

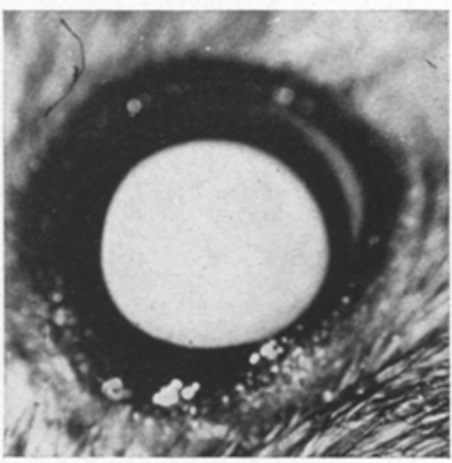

f

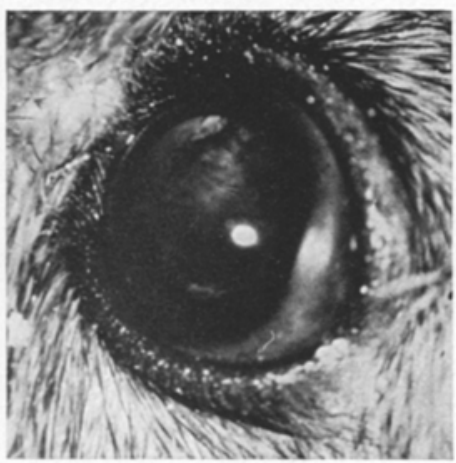

Fig. 9. Photographs of lens lesions observed in tuco-tucos ( $\times$ 6). a) a refractive change seen at the periphery; b) vacuoles at the lens perjphery; c) lens with scattered vacuoles; d) polar opacity; e) semi-dense, diffuse cataract; f) dense, diffuse cataract; g) early stage of regression: peripheral water clefts; h) later stage of regression: more water clefts and less dense opacity ; i) last stage of regression: indications of recent opacity and refractive index changes

and partial (Fig. 9e) or complete (Fig. 9f) opacifications were also observed. The mean blood sugar level of $\mathrm{F}_{1}$ animals with normal lenses was $101 \pm 6 \mathrm{mg}$ per cent compared with $150 \pm 13 \mathrm{mg}$ per cent for the group showing vacuoles $(0.001<P<0.01)$ and $220 \pm 11 \mathrm{mg}$ per cent for the group with more advanced cataract
$0.01<P<0.05$ ). A total of 204 eyes were examined again after an interval since the first examination of 1 month for the parent colony and 3 months for the $\mathrm{F}_{1}$ animals. In 138 lenses $(68 \%)$ no changes had occurred. In 38 lenses $(19 \%)$, either new cataractous changes had appeared or existing lesions had progressed 
in a direction confirming the postulated sequence shown in Figs. 9a-f. In 28 lenses $(13 \%)$ regression had occurred, in one case from floccular opacities to complete normality, and in others from complete opacity to a smaller lesion with peripheral scalloping and 'water clefts' (Figs. $9 \mathrm{~g}-\mathrm{i}$ ). During this period between examinations the mean blood sugar of all the animals except those on the restricted Diet B (see Fig. 4) fell by $26 \mathrm{mg}$ per cent. Fig. 11 shows the sequential trend in blood sugar levels of all animals showing lens lesions according to changes in the less affected eye of a pair. A clear relation was seen between the condition of the lens and blood sugar changes.

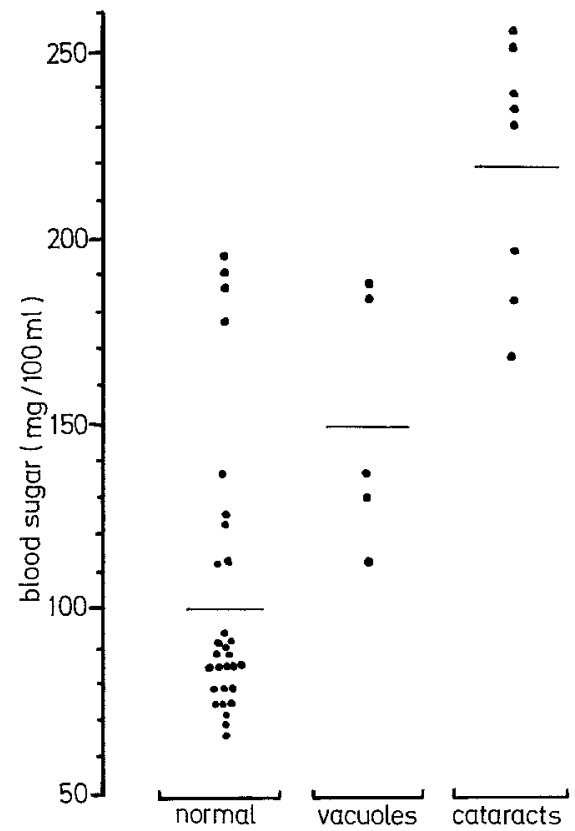

Fig. 10. Distribution of blood sugar concentrations in the $\mathrm{F}_{1}$ generation of tuco-tucos according to lens appearance

Table 2. Analysis of causes of death in the tuco-tuco colony

\begin{tabular}{lll}
\hline & Animals killed & $\begin{array}{l}\text { Animals found } \\
\text { dead }\end{array}$ \\
\hline Experimental & 10 & \\
Infection & 5 & 11 \\
Injury & 4 & 10 \\
Acute loss of body & & \\
$\quad$ weight & 13 & 33 \\
Unknown & 32 & 54 \\
Total & 32 & \\
\hline
\end{tabular}

\section{Mortality}

Eighty-six animals were investigated post mortem and their causes of death are shown in Table 2. No deaths from ketoacidosis were diagnosed and postmortem bladder urine contained glucose but no ketones. In one animal before death, the blood sugar level was $325 \mathrm{mg}$ per cent although it had been $87 \mathrm{mg}$ per cent a month previously. Diabetes did not initially appear to be the direct cause of death. However, an analysis in March 1968 of blood sugar levels of animals maintained on the unrestricted diet shows significantly higher levels in those animals that were subsequently found dead (Table 3). This suggests that hyperglycaemia, or predisposition to it, played a role in the deaths.

\section{Histological observations}

\section{Pancreas}

In the majority of normoglycaemic animals, islets were indistinguishable in number and size from those of albino mice, being evenly distributed throughout the pancreas and constituting an estimated $2-4 \%$ of total pancreatic mass. Within each islet, approximately

Table 3. A comparison of mean blood sugar level (March 1968) of tuco-tucos on unrestricted diet which subsequently died, with that of animals still living or killed for experimental purposes

\begin{tabular}{|c|c|c|c|}
\hline \multicolumn{2}{|r|}{ Cataractous } & \multicolumn{2}{|r|}{ Non-cataractous } \\
\hline No. & $\begin{array}{l}\text { Mean blood sugar } \\
\pm \text { S.E. } \\
\text { (mg per cent) }\end{array}$ & No. & $\begin{array}{l}\text { Mean blood sugar } \\
\pm \text { S.E. } \\
\text { (mg per cent) }\end{array}$ \\
\hline & Found dead & & Found dead \\
\hline 17 & $160.0 \pm 15.5^{\mathrm{a}}$ & 13 & $101.0 \pm 8.8^{\mathrm{a}}$ \\
\hline & Living or killed & & Living or killed \\
\hline 18 & $104.0^{\circ} \pm 6.2^{\mathrm{a}}$ & 24 & $71.0 \pm 3.6^{\mathrm{a}}$ \\
\hline
\end{tabular}

a Significantly different $0.001<P<0.005$.

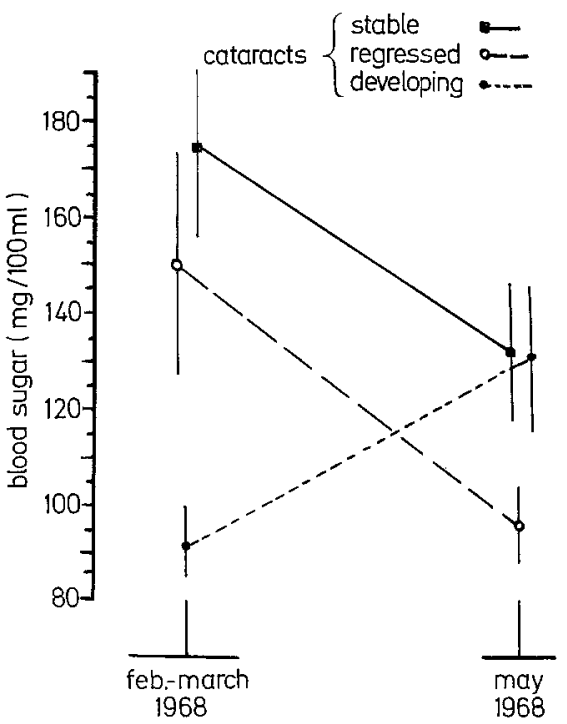

Fig. 11. Diagram to show the change in mean blood sugar concentrations ( \pm S.E.M.) in the colony between two examinations according to the lens condition

$80 \%$ of the cells were beta-cells but, contrary to the appearances in the sand rat [11] and the spiny mouse [12] where alpha-cells are peripherally sited, in the tuco-tuco they were centrally arranged in common with a variety of hot-climate rodents [13]. Marked islet 
cell hyperplasia was seen in some glands (Fig. 3) and it was estimated that up to $15 \%$ of each pancreas was composed of islet tissue. Individual islets were larger and more numerous than in 'normal' glands and showed a higher proportion of beta-cells, although some alpha-cells were always identifiable. These appearances were invariably seen in animals on Diet A, with one exception, normoglycaemic and without cataracts. Varying degrees of beta-cell degranulation were seen in hyperglycaemic animals mostly with, but occasionally without, islet hyperplasia. In two animals, both of the parent colony, the majority of the islets showed some degree of hyalinisation, which could be stained positively for amyloid with congo-red. No examples of glycogen vacuolation of beta-cells were noted.

The islet changes are similar to those which have been described for the spiny mouse and sand rat, the lack of glycogen vacuolation reflecting the absence of severe hyperglycaemia. In some animals the degree of islet hypertrophy matched that noted in the spiny mouse $[4]$.

\section{Kidney}

Macroscopically, the renal papillae were noted to be extremely long, as in the sand rat and spiny mouse, which occupy arid terrains. This undoubtedly reflects the increased tubular length described by Sperber [14] as being a feature of desert dwelling rodents, and which he showed to be correlated with increased water concentrating ability. Glomeruli in animals from the parent colony, whether diabetic or not, showed only diffuse argyrophilia of the mesangium and sometimes a degree of basement membrane thickening in peripheral capillary loops not seen in normoglycaemic members of the $\mathbf{F}_{\mathbf{1}}$ generation. Glomeruli of the $\mathbf{F}_{1}$ generation showed a greater variety of changes, but it was again difficult to derive any clear relationship between the observed changes and the diabetic status of the individual animal. Cystic capillary dilatation, occasionally occupying as much as one third of the glomerular diameter was identified in a number of animals, mostly hyperglycaemic. The appearances were identical to those described by Huckel [15] and Anderson [16] in human diabetics. Individual lesions were packed with red cells and the capillary wall did not appear thickened. The appearance of small aggregates of silver positive material in the mesangial region was a common feature in normoglycaemic animals. Some animals, however, showed marked increases in mesangial argyrophilia and although often present, associated thickening of peripheral capillary walls was not always identifiable. There was no evidence of nodular lesions of the glomerular tufts and glycogen could not be identified histochemically in the renal tubules. Some hyaline thickening of afferent arterioles was noted, particularly in animals of the parent generation.

Renal changes are similar to those reported in man, the lack of nodular glomerular lesions possibly reflect- ing the comparatively shorter duration of diabetes in the tuco-tuco. Although no quantitation of basement membrane thickness was attempted by electron microscopy, this species may be a suitable model for assessing the association between such microvascular pathology and the presence of hyperglycaemia and related metabolic factors.

\section{Lens}

Irregular and variable size vacuoles were identified histologically in all lenses previously noted, during in-vivo examination, to have any abnormality in excess of refractive change. Many lenses showed additional marked disruption of lens cortex (Fig. 2), as previously described in hyperglycaemic sand rats by Hackel et al. [11].

\section{Discussion}

Although there are no data on blood sugar levels or cataract occurrence in this species of tuco-tuco in the wild, Darwin [17] was told that many $C$. brasiliensis were blind when caught. Lens lesions were not observed when our tuco-tucos were caught, and no lens changes were reported in wild $C$. torquatus [18]. The development of hyperglycaemia in the $C$. talarum colony is associated with increase in weight, presumably due to inactivity coupled with the ready availability of high calorie food in the form of compound diet pellets. In these respects the tuco-tuco resembles the spiny mouse [4] and the sand rat [3], but the high prevalence of hyperglycaemia in the tuco-tuco colony is of interest.

Lens changes were clearly related to elevated blood sugar levels, as measured by the ferricyanide method. Lens lesions were noted at blood sugar levels considerably lower than those found to be necessary for the production of cataracts in alloxan-diabetic rats [19]; this was particularly true for the parent colony. Such a phenomenon may be due to a species difference in lens susceptibility to hyperglycaemia, to additional cataractogenic factors in the diet, or possibly to removal of hypoglycaemic agents in the natural diet. Preliminary studies of the urinary sugars in the tucotuco by thin-layer chromatography have revealed small quantities of galactose. This may indicate a co-existent metabolic defect in the galactose pathway, which may be contributory to cataract formation. The regressive lens changes noted have not been confidently recorded previously, either in animals or man.

No suggestion can be made about the mode of inheritance of this form of diabetes. The maternallitter blood sugar correlation indicates an important genetic element, but the lack of any clear division into 'diabetic' and 'non-diabetic' groups on the basis of weight, random blood sugar values, glucose tolerance tests or insulin sensitivity, renders multifactorial inheritance rather more likely than a single gene determinant. Hyperglycaemia was more prevalent and greater in degree in the $F_{1}$ animals than in the parents 
after identical or shorter periods of exposure to the compound pellet diet. Although negative correlation of blood sugar with age within the $\mathbf{F}_{1}$ generation did not reach significance, it does imply a greater susceptibility of younger animals to hyperglycaemia. The greater prevalence of cataracts and their more advanced form in the $\mathbf{F}_{\mathbf{1}}$ generation is probably partly due to the greater frequency of hyperglycaemia in this group. However, it has been shown that young rats are more susceptible to cataract than are older rats for a given degree of alloxan-induced hyperglycaemia [20]. To test this possibility in the tuco-tuco, an arbitrary blood sugar value of $130 \mathrm{mg}$ per cent was chosen. In the $\mathrm{F}_{I}$ generation 10 animals exceeded this value and $8(80 \%)$ also had lens abnormalities. In the parent colony, only 4 of 11 animals $(36 \%)$ with blood sugar levels over $130 \mathrm{mg}$ per cent had lens changes $\left(\mathrm{X}^{2}=4.08,0.025<\right.$ $P<0.005$ ). This lends some support to the concept of inverse age-related lens susceptibility to hyperglycaemia.

The metabolic lesion which predisposes to the dietinduced hyperglycaemia in this species cannot yet be defined. The extreme tolerance to insulin suggests peripheral interference with insulin action, although it is possible that bovine insulin lacks the species specificity necessary for hypoglycaemic effect in this animal. The way in which deaths in the colony were related to hyperglycaemia is obscure; there was no evidence of generalised infection and none of the animals appeared to succumb from diabetic ketosis. However, electrolyte disturbances secondary to hyperglycaemia or hyperosmolar coma remain distinct possiblities.

The symptoms exhibited by this colony of tucotucos indicate that these animals show a mild form of diabetes mellitus, comparable to maturity onset diabetes in man. Thus the tuco-tuco may provide a useful model for studies in this field although several points, such as the respective roles of diet and exercise, additional diabetogenic effects and methods of overcoming the associated infertility, require further study. It is unlikely that the tuco-tuco is unique and the effect of diabetes on mortality and reproduction suggested by these and other studies may have significance for the health of other captive species.

Acknowledgements: Our thanks are due to Professor W.J.H. Butterfield, Dr. L.G. Goodwin, and Dr. I.W. Rowlands for their help and encouragement. The field collection of the tuco-tucos was financed by the Royal Society, the Medical Research Council and the Wellcome Trust. The work was supported by the Medical Research Council (P.H.W. and E.F.) and the Ford Foundation (B.J.W.).

We are grateful to $\mathrm{Mr}$. J. Trethewey for his helpful discussions and eriticisms and to Miss M.J. Whichelow for the blood sugar determinations. Figure 1 was taken by Mr. M. Lyster of the Zoological Society of London:
Figures $9 \mathrm{~b}, \mathrm{c}, \mathrm{d}, \mathrm{f}, \mathrm{h}$ and 6 are published by permission from Nature, Lond. [6] and Fig. $9 \mathrm{a}$ and $4 \mathrm{~g}$ by permission from the Zoological Society of London.

\section{References}

1. Meir, H.: Diabetes mellitus in animals: a review. Diabetes $\mathbf{9}, 485-489(\mathbf{1 9 6 0 )}$.

2. Wilkinson, J.S.: Spontaneous diabetes in domestic animals. Vet. Rev. Annot. 3, 69-96 (1957).

3. Schmidt-Nielsen, K., Haines, H.B., Hackel, D.E. Diabetes mellitus in the sand rat induced by standard laboratory diets. Science 143, 689-690 (1964).

4. Gonet, A.E., Mougin, J., Renold, A.E.: Hyperplasia and hypertrophy of the islets of Langerhans, obesity and diabetes in the mouse (Acomys dimidiatus). Acta eadocr. Suppl. 100, 135 (1965).

5. Rabb, G.B., Getty, R.E., Williamson, W.M., Lombard, L.S.: Spontaneous diabetes in tree shrews (Urogale everetti). Diabetes 15, 327-330 (1966).

6. Wise, P.H., Weir, B.J., Hime, J.M., Forrest, E. Implications of hyperglycaemia and cataract in a colony of tuco-tucos (Ctenomys talarum). Nature (Lond.) 219, $1374-1376$ (1968).

7. Weir, B.J.: A trapping technique for tuco-tucos, Ctenomys talarum. J. Mammal, 52, 836-839 (1971)

8. Riley, V.: Adaptation of orbital bleeding technique to rapid serial blood studies. Proc. Soc. Exp. Biol. 104, $751-754(1960)$.

9. Whichelow, M.J., Wigglesworth, A., Cox, B.D., Butterfield, W.J.H., Abrams, M.E.: Critical blood sugar moasurements in diabetes detection and diagnosis. Diabetes 16, 219-226 (1967).

10. Weir, B.J.: Reproduction in a colony of diabetic tucotucos (Ctenomys talarum). In preparation.

11. Hackel, D.E., Schmidt-Nielsen, K., Haines, H. B. Mikat, E.: Diabetes mellitus in the sand rat: Pathological studies. Lab. Invest. 14, 200-207 (1965).

12. Pictet, R., Orci, L., Gonet, E.A., Rouiller, C., Renold, A.E.: Ultrastructural studies of the hyper. plastic islets of Langerhans of spiny mice (Acomys cahirinus) before and during hyperglycaemia. Diabetologia 3, 188-211 (1967).

13. Quay, W.B.: Pancreatic islets of desert rodents. Am. Mid. Nat. 64, 342-348 (1960).

14. Sperber, I.: Studies on the mammalian kidney. Zoologiska Bidrag fran Uppsala 22, 249-431 (1944).

15. Huckel, S.: Eigenautge Glomerulus veranderungen bes Benigner nephroshlerose. Verh. dtsch. path. Ges. 31, $392-397(1938)$.

16. Anderson, G.S.: The pathogenesis of diabetic glomerulosclerosis. J. Path. Bact. 67, $241-245$ (1954).

17. Darwin, C.: Journal of a voyage round the world, pp. $69-71$. London: Nelson \& Sons 1890.

18. Talice, R.V., Momigliano, E.: La vision del roedor Ctenomys torquatus. Archives Soc. Biol. Montevideo 21, $173-178(1951)$

19. Patterson, J.M.: Diabetic cataracts: a review of experimental studies. Diabetes 5, $93-97$ (1956).

20. Charalampous, F.C., Hagstedt, D.M.: Effect of age and diet on development of cataracts in the diabetic rat. Amer. J. Physiol. 161, 540-544 (1950).

Dr. B.J. Weir,

Wellcome Institute of Comparative Physiology,

Zoological Society of London,

Regent's Park, London N.W. 1., England 